\title{
Faktor-Faktor yang Memengaruhi Non Performing Financing pada Bank Umum Syariah Indonesia Periode 2010-2014
}

\section{Determinant of Non Performing Financing in Islamic Banking Indonesia, 2010-2014}

\author{
Yulya Aryani ${ }^{1}{ }_{\text {Lukytawati Anggraeni }}{ }^{2}$, Ranti Wiliasih ${ }^{3}$ \\ ${ }^{\mathbf{1}}$ Alumnus Program Studi Ilmu Ekonomi Syariah, Institut Pertanian Bogor, Email \\ yulya_aryani@yahoo.co.id \\ ${ }^{2}$ Dosen Program Studi Ekonomi Studi Pembangunan, Institut Pertanian Bogor, Email \\ lukytawati_anggraeni@yahoo.com \\ ${ }^{3}$ Dosen Program Studi Ilmu Ekonomi Syariah, Institut Pertanian Bogor, Email rarantiti@gmail.com
}

\begin{abstract}
The objective of this study is to determine the internal and external factors affected nonperforming financing in Islamic Banks Indonesia, 2010-2014. The samples used were 11 Islamic Banks in Indonesia 2010-2014. This study used panel data with annual data obtained from the bank's 2010 to 2014 annual reports of banks. The results showed that the Capital Adequacy Ratio (CAR), Bank size, overhead cost and SBIS rate have a significant negative effect on Non Performing Financing, while the FDR, NIM, KAP and BI rate have a significant positive effect on Non-Performing Financing. Commercial Bank needs to monitor the level of Capital Adequacy Ratio (CAR), Bank size and improve the quality of operational management on overhead cost. In addition, Islamic Banks should be more sensitive to macroeconomic conditions, especially the level of BI rate and yield rate of SBIS so it can determine precisely the financing policy in order to control the level of NPF at a reasonable level.
\end{abstract}

Keywords: Non Performing Financing, overhead cost, SBIS rate, BI rate.

Abstrak. Penelitian ini bertujuan untuk mengetahui faktor internal dan eksternal yang memengaruhi pembiayaan bermasalah pada Bank Umum Syariah di Indonesia periode 2010-2014. Sampel yang digunakan adalah 11 Bank Umum Syariah di Indonesia periode 2010-2014. Penelitian ini menggunakan metode data panel dengan data tahunan dari laporan tahunan perbankan 2010-2014. Hasil penelitian menunjukkan bahwa Capital Adequacy Ratio (CAR), Bank size, biaya overhead dan SBIS rate memiliki efek negatif signifikan pada Non Performing Financing (NPF), sedangkan Financing to Deposit Ratio (FDR), Net Income Margin (NIM), Kualitas Aktiva Produktif (KAP) dan BI rate memiliki efek positif signifikan terhadap Non Performing Financing. Bank Umum Syariah perlu melakukan pengawasan terhadap tingkat Capital Adequacy Ratio (CAR), Bank size dan meningkatkan kualitas manajemen operasional pada biaya overhead. Selain itu, Bank Umum Syariah harus lebih peka terhadap kondisi makroekonomi terutama tingkat BI rate dan tingkat imbal hasil SBIS sehingga dapat menentukan kebijakan pembiayaan secara tepat agar dapat mengendalikan tingkat NPF pada taraf yang wajar.

Kata Kunci: Non Performing Financing, biaya overhead, SBIS rate, BI rate 


\section{Pendahuluan}

Perbankan merupakan sarana strategis dalam pembangunan ekonomi. Peran strategis tersebut terutama disebabkan oleh fungsi utama bank sebagai penghimpun dan penyalur dana dari dan ke masyarakat dalam rangka mencapai tujuan pembangunan nasional. Menurut data Bank Indonesia tercatat ada 12 Bank Umum syariah (BUS), 22 bank syariah dalam bentuk Unit Usaha Syariah (UUS), dan 163 Bank Pembiayaan Rakyat Syariah (BPRS) yang terdaftar di Bank Indonesia. Perkembangan jumlah bank syariah tersebut sejalan dengan perkembangan kinerja perbankan syariah yang dapat dilihat dari jumlah aset dan banyaknya pembiayaan yang disalurkan.

Sepanjang tahun 2010 hingga tahun 2015 nilai aset dan pembiayaan pada Bank Umum Syariah mengalami pertumbuhan yang cukup signifikan. Tahun 2010 pertumbuhan aset pada Bank Umum Syariah 19.81\% meningkat menjadi 47.65\% di tahun 2011. Pada tahun 2012 sampai 2014 nilai pertumbuhan aset Bank Umum Syariah menunjukkan tren menurun, dimana pada akhir tahun 2014 pertumbuhan aset Bank Umum Syariah sebesar 9.8\% melambat dari tahun sebelumnya sebesar 24.2\%. Secara nominal pembiayaan Bank Umum Syariah mengalami peningkatan setiap tahunnya. Tingkat pertumbuhan pembiayaan Bank Umum Syariah pada tahun 2011 sebesar 50.56\% merupakan nilai tertinggi sepanjang tahun 2010 sampai 2014.

Fungsi intermediasi yang dilakukan Bank Umum Syariah dapat dilihat dari besaran nilai financing to deposit ratio (FDR). FDR menggambarkan perbandingan antara besarnya kemampuan Bank Umum Syariah dalam menyalurkan pembiayaan dengan jumlah seluruh dana yang dapat dihimpun dari masyarakat. Nilai FDR dari tahun 2010 sampai tahun 2014 memiliki nilai yang berfluktuatif dan cenderung menurun. Tahun 2013 nilai FDR pada Bank Umum Syariah mencapai $100.32 \%$ dan merupakan rasio tertinggi selama lima tahun terakhir. Akhir tahun 2014 nilai FDR pada Bank Umum Syariah mengalami penurunan sebesar $8.82 \%$ menjadi $91.50 \%$. Penurunan nilai FDR menunjukkan fungsi intermediasi yang dilakukan oleh Bank Umum Syariah mengalami penurunan. Pertumbuhan pembiayaan yang cukup tinggi dengan kinerja fungsi intermediasi selama tahun 2005 hingga 2014 ternyata tidak diikuti dengan meningkatnya kualitas pembiayaan yang disalurkan.

Pembiayaan merupakan aktivitas yang menjadi sumber pendapatan utama Bank Umum Syariah. Risiko gagal bayar yang mungkin terjadi membuat Bank Umum Syariah perlu memperhatikan risiko terkena pembiayaan bemasalah. Tingkat terjadinya pembiayaan bermasalah digambarkan dengan rasio NPF. Semakin rendah rasio NPF, semakin rendah tingkat pembiayaan bermasalah yang terjadi berarti semakin baik kondisi bank tersebut. NPF merupakan indikator dalam menilai kinerja fungsi bank, dimana fungsi bank adalah sebagai lembaga intermediasi. Tingkat NPF yang tinggi menunjukkan kesehatan bank yang rendah karena hal ini mengindikasikan banyak terjadi pembiayaan bermasalah dalam kegiatan operasional bank. Menurut Diyanti (2012) pembiayaan yang disalurkan oleh perbankan syariah tidak semua pembiayaan yang memiliki tingkat kolektabilitas yang baik, hal ini terjadi karena kegiatan operasional penyaluran pembiayaan yang merupakan sumber pemasukan utama bank tersebut akan menghadapi berbagai risiko terutama risiko pembiayaan, operasional dan risiko pasar. 


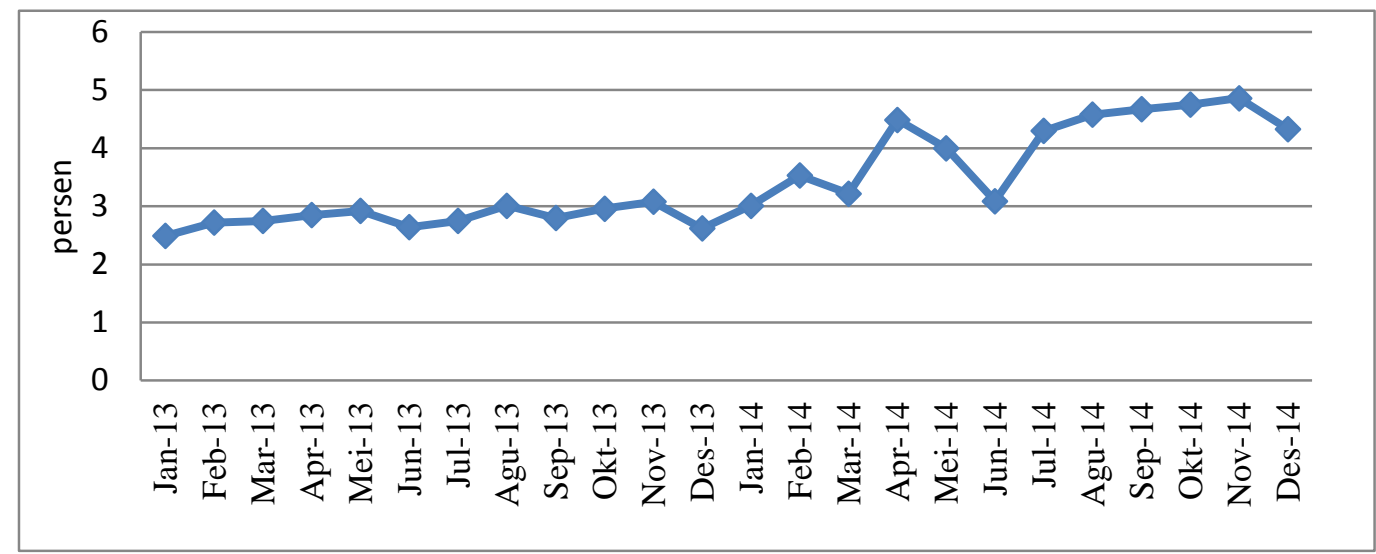

Sumber: Statistik Perbankan Syariah BI 2014 (diolah)

\section{Gambar 1 Perkembangan NPF pada Bank Umum Syariah pada 2013-2014}

Gambar 1 menunjukkan fluktuasi nilai NPF dari tahun 2013 hingga 2014 yang relatif tinggi. Pada Januari 2013 sampai April 2014 nilai NPF menunjukkan tren meningkat, dimana pada April 2014 terjadi kenaikan NPF yang relatif tinggi mencapai angka $4 \%$ dan cenderung turun hingga Juni 2014. Pada Juli 2014 nilai NPF sebesar $4.31 \%$ dan terus meningkat mencapai $4.86 \%$ di November 2014 dan kembali turun menjadi 4.33\% di akhir tahun 2014. Nilai NPF yang tinggi pada akhir tahun 2014 tersebut masih di bawah ambang batas NPF yang ditetapkan oleh Bank Indonesia yaitu sebesar $5 \%$.

Tingkat pertumbuhan pembiayaan yang tinggi, diikuti dengan tingginya nilai FDR ternyata juga berdampak pada rasio NPF yang tinggi. Nilai NPF di akhir tahun 2014 perlu mendapat perhatian khusus karena dapat menimbulkan kerugian bagi bank. Kerugian tersebut dapat mengganggu neraca bank, sehingga mengurangi kemampuan aktivanya. Jika kerugian tersebut cukup besar, maka bukan tidak mungkin bank akan mengalami likuidasi. Ismail (2010) menyatakan keberadaan NPL dalam jumlah besar dapat berdampak pada kerugian bank yaitu kerugian karena tidak diterimanya kembali dana yang telah disalurkan dan pendapatan bunga tidak dapat diterima, artinya bank kehilangan kesempatan mendapat bunga. Selain itu NPL juga berdampak pada berkurangnya pendapatan dari kredit tersebut yang dapat mengurangi laba bank dan kemampuan memberikan kredit.

Telah banyak studi yang meneliti determinan kredit bermasalah. Erdinc dan Abazi (2014) Wu et all (2003) serta Berger \& De Young (1997) mengemukakan bahwa kondisi makroekonomi, kondisi pasar real estate dan kebijakan kredit bank memengaruhi NPL. Selain itu, adanya krisis finansial dan kegagalan bank juga memengaruhi besaran nilai NPL. Mileris (2012) menyatakan bahwa kondisi makroekonomi berpengaruh kuat terhadap NPL. Scarica (2014) menyatakan bahwa kondisi makroekonomi seperti GDP, tingkat pengangguran dan tingkat inflasi memengaruhi NPL.

Dari sisi internal atau karakteristik perbankan Socol dan Danuletiu (2013) serta Marki (2013) menyatakan variabel internal perbankan yang memengaruhi tingkat NPL meliputi Return On Asset, Return On Equity, Loan to Deposit Ratio. Adebolla (2011) menyatakan bahwa variabel makroekonomi yang memengaruhi NPF pada Bank Syariah Malaysia meliputi Industrial Production Index, income rate dan producer price index. Penelitian terkait faktor-faktor yang memengaruhi pembiayaan bermasalah pada perbankan syariah belum banyak dilakukan. Hal ini sangat menarik untuk dianalisis lebih lanjut sehingga dapat memahami dampak dari keberadaan NPF tersebut. 
Berdasarkan penjelasan di atas, maka permasalahan yang dapat dirumuskan dalam penelitian ini adalah apakah faktor internal (karakteristik perbankan) dan eksternal (kondisi makroekonomi) berpengaruh terhadap tingkat Non Performing Financing pada Bank Umum Syariah Periode 2010-2014.

Penelitian ini dilakukan untuk menganalisis faktor faktor internal (karakteristik perbankan) dan eksternal (kondisi makroekonomi) berpengaruh terhadap tingkat Non Performing Financing pada Bank Umum Syariah. Untuk mengetahui hal tersebut maka penelitian ini akan mengkaitkan sejauh mana kinerja perbankan syariah dan kategori kondisi makroekonomi, mempengaruhi rasio pembiayaan bermasalah pada Bank Umum Syariah.

Ruang lingkup penelitian ini dibatasi hanya pada faktor-faktor yang memengaruhi Non Performing Financing pada Bank Umum Syariah di Indonesia. Perbankan yang menjadi objek dalam penelitian ini adalah 11 Bank Umum Syariah yang sudah terdaftar. Dikarenakan adanya terbatasnya ketersediaan data publikasi terhadap perbankan syariah maka penelitian ini hanya menggunakan data tahuanan yang dimulai dari tahun 2010 sampai dengan 2014.

Faktor-faktor yang digunakan dalam penelitian ini dibatasi hanya pada beberapa variabel. Variabel yang digunakan untuk menggambarkan kinerja perbankan diantaranya yaitu Non Performing financing, Financing to Deposit Ratio, Capital Adequaacy Ratio, biaya overhead, Net Income Margin, bank size, kualitas aktiva produktif, penyisihan penghapusan aktiva produktif. Lalu Variabel yang menggambarkan kondisi makroekonomi Indonesia diantaranya exchange rate, SBIS rate, BI rate.

\section{Metode Penelitian}

\subsection{Jenis dan Sumber Data}

Data yang digunakan yaitu data sekunder berupa data deret waktu (time series) dengan frekuensi data tahunan dari tahun 2010 sampai 2014, sedangkan data cross section meliputi 11 Bank Umum Syariah di Indonesia. Adapun kriteria dalam pemilihan sampel adalah mempunyai laporan keuangan paling lengkap dan telah dipublikasikan, selain itu laporan keuangan harus mempunyai tahun buku berakhir 31 Desember. Data internal perbankan dan makroekonomi yang digunakan bersumber dari publikasi Bank Indonesia antara lain Statistik Perbankan Syariah Bank Indonesia (SPS-BI) dan juga menggunakan data pelengkap lainnya dari literatur-literatur yang berkaitan, jurnal, buku, dan dari media internet.

\subsection{Metode Analisis dan Pengolahan Data}

Penelitian ini menggunakan metode analisis yang bersifat deskriptif dan kuantitatif. Alat analisis yang digunakan dalam penelitian ini adalah metode panel data statis. Metode ini digunakan dengan mengombinasikan data time series $(\mathrm{t})$ dengan data cross section (n). Salah satu kelebihan dari pengunaan model data panel adalah dapat mengendalikan heterogenitas antar individu atau unit crossection. Terdapat tiga metode estimasi regresi data panel yaitu Pooled Least Square (PLS), Fixed Effect Model (FEM), dan Random Effect Model (REM)

\subsubsection{Pooled Least Square Model}

Pooled Least Square Model (PLS) menggunakan gabungan dari seluruh data (pooled), sehingga terdapat NxT observasi, dimana $\mathrm{N}$ menunjukkan jumlah unit cross section dan $\mathrm{T}$ menunjukkan jumlah time series yang digunakan (Firdaus, 2012). Persamaan pada estimasi menggunakan PLS dapat dituliskan dalam bentuk sebagai berikut :

Yit $=\alpha+\beta j x j i t+\epsilon i$

Jurnal Al-Muzara'ah Vol.4, No.1, 2016

(ISSN p: 2337-6333; e: 2355-4363) 
Keterangan :

\begin{tabular}{|c|c|}
\hline $\begin{array}{l}= \\
=\end{array}$ & $\begin{array}{l}\text { nilai variabel penjelas (explanatory variabel) ke-j untuk setiap cross section } \\
\text { slope untuk variabel ke-j yang konstan antar waktu dan cross section }\end{array}$ \\
\hline$=$ & komponen error setiap unit cross section ke-i pada periode waktu $t$ \\
\hline$=$ & intercept yang konstan antar waktu dan cross section \\
\hline
\end{tabular}

\section{Fixed Effect Model}

Fixed effect model (FEM) memasukan unsur variabel dummy sehingga intercept $\alpha$ bervariasi antar individu maupun antar unit waktu. Penggunaan dummy pada metode ini mengakibatkan metode ini juga dikenal dengan Least Square Dummy Variabel (LSDV). FEM lebih tepat digunakan jika data yang diteliti pada tingkat individu serta jika terdapat korelasi antara eit dan Xit

$Y_{i t}=\sum \alpha i D i+\beta^{j} x^{j} i t+\epsilon i t$

keterangan :

Yit $=$ nilai variabel terikat (dependent variabel) untuk setiap unit cross section

$\mathrm{xit}=$ nilai variabel penjelas (explanatory variabel) ke-j untuk setiap cross section

$\alpha=$ intercept model yang berubah-ubah antar cross section

$\beta \mathrm{j}=$ slope untuk variabel ke-j yang konstan antar waktu dan cross section

$€$ it $=$ komponen error untuk unit cross section ke-i pada periode waktu $t$

$\mathrm{D}=$ Peubah dummy

\section{Random Effect Model}

Random Effect Model (REM) disebut juga komponen error (error komponent model) karena di dalam model ini parameternya berbeda antar unit cross section maupun antar waktu yang dimasukan ke dalam error. Persamaan pada estimasi menggunakan REM dapat dituliskan dalam bentuk sebagai berikut :

$Y i t=\alpha 0+\beta j x j i t+\epsilon i t$

$\epsilon i t=u i t+v i t+w i t$

dimana :

$\sim(, u 2) v i$

$\sim(, v 2)$

= komponen cross section error

$w i \sim(, w 2)$

$=$ komponen time series error

$=$ komponen kombinasi error

Asumsi yang digunakan dalam model ini adalah error secara individual tidak saling berkorelasi, begitu pula dengan error kombinasinya. Penggunaan pendekatan REM dapat menghemat degree of freedom dan tidak mengurangi jumlahnya seperti pada pendekatan FEM. Hal ini berimplikasi pada parameter hasil estimasi menjadi efisien. Semakin efisien maka model akan semakin baik (Firdaus, 2012).

\subsection{Pengujian Model Panel Statis}

Untuk memilih model mana yang paling, maka terdapat bebrapa pengujian yang dapat dilakukan, antara lain :

\subsubsection{Chow Test}

Chow test atau pengujian $\mathrm{F}$ statistik adalah pengujian untuk memilih apakah model yang digunakan antara Pooled Least Square Model atau Fixed Effect Model. Pengujian ini dilakukan Jurnal Al-Muzara'ah Vol.4, No.1, 2016 
dengan hipotesis sebagai berikut :

$\mathrm{H}_{0}:$ Pooled Least Square Model

$\mathrm{H}_{1}$ : Fixed Effect Model

Dasar penolakan terhadap hipotesis nol $\left(\mathrm{H}_{0}\right)$ tersebut adalah dengan menggunakan F-statistik seperti dirumuskan oleh chow:

$F-$ Statistik $=\frac{(R R S S-U R S S) /(N-1)}{U R S S /(N T-N-K)} \sim F a(N-1, N T-N-K)$

dimana :

RRSS = Restricted Residual Sum Square (Sum Square Residual PLS)

URSS = Unrestricted Residual Sum Square (Sum Square Residual PLS)

$N \quad=$ jumlah data cross section

$T=$ jumlah data time series

$K=$ jumlah variabel independen

Pengujian ini mnengikuti distribusi F yaitu $\mathrm{F} \alpha(\mathrm{N}-1, \mathrm{NT}-\mathrm{N}-\mathrm{K})$. Jika Chow Statistic (Fstatistik) lebih dari taraf nyata $(F h i t>F \alpha)$ maka cukup bukti untuk menolak H0, artinya asumsi semua intersep konstan tidak benar dan model yang sebaiknya digunakan yaitu Fixed Effect Model.

\subsubsection{Hausman Test}

Hausman Test adalah pengujian statistik sebagai dasar pertimbangan dalam memilih apakah menggunakan Fixed Effect Model atau Random Effect Model. Penggunaan Fixed Effect Model menggandung suatu unsur trade off yaitu hilangnya derajat bebas dengan memasukan variabel dummy. Penggunaan Random Effect Model juga harus memperhatikan ketiadaan pelanggaran asumsi dari setiap komponen galat. Pengujian ini dilakukan dengan hipotesis sebagai berikut :

$\mathrm{H}_{0}:$ Random Effect Model

$\mathrm{H}_{1}$ : Fixed Effect Model

Dasar penolakan terhadap hipotesis nol $\left(\mathrm{H}_{0}\right)$ dengan menggunakan statistik Hausman yang dirumuskan sebagai berikut:

$H=(B R E M-B F E M)^{\prime}(M F E M-M R E M)-1(B R E M-B F E M) \sim X 2(k)$

Penolakan $\mathrm{H} 0$ dengan membandingkan statistik Hausman denga Chi-squared. Jika nilai H hitung lebih besar dari tabel chi-squared maka cukup bukti untuk menolak H0 sehingga model yang digunakan adalah Fixed Effect Model, dan begitu pula sebaliknya.

\subsection{Metode Evaluasi Model}

Model estimasi regresi linear yang ideal dan optimal harus menghasilkan estimator yang memenuhi kriteria Best Linear Unbiased Estimator (BLUE) yang antara lain :

a. Estimator Linear artinya adalah estimator merupakan sebuah fungsi linear atas sebuah variabel dependen stokastik.

b. Estimator tidak bias artinya nilai ekspektasi sesuai dengan nilai yang sebenarnya.

c. Estimator harus mempunyai varians yang minimum. Estimator yang tidak bias dan memiliki varians yang minimum disebut estimator yang efisien.

Terdapat beberapa permasalahan yang dapat menyebabkan sebuah estimator tidak dapat memenuhi asumsi kriteria BLUE antara lain sebagai berikut :

1. Uji Normalitas

Uji normalitas dapat dilihat dengan melihat nilai Jarque Bera Test atau dengan melihat plot 
dari sisaan. Hipotesis dalam pengujian normalitas adalah :

$\mathrm{H}_{0}=$ Residual berdistribusi normal

$\mathrm{H}_{1}=$ Residual tidal berdistribusi normal

Dasar penolakan $\mathrm{H}_{0}$ dengan membandingkan nilai probabilitas Jarque Bera dengan taraf nyata $\alpha$ sebesar 0.05 dimana jika lebih besar dari taraf nyata terebut menandakan tidak cukup bukti untuk menolak $\mathrm{H}_{0}$ sehingga residual berdistribusi normal.

\section{Uji Multikolinearitas}

Multikolinearitas adalah kondisi dimana peubah-peubah bebas memiliki korelasi diantara satu dengan yang lainnya. Jika peubah-peubah bebas memiliki korelasi sama dengan satu satu berkorelasi sempurna mengakibatkan koefisien regresi menjadi tidak dapat diperkirakan dan nilai standar error setiap koefisien regresi menjadi tak hingga. Gejala multikolinearitas ini dapat dideteksi dari nilai $\mathrm{R}^{2}$ tinggi tetapi tidak terdapat atau sedikit sekali koefisien dugaan yang berpengaruh nyata dan tanda koefisien regresi tidak sesuai teori (Gujarati, 2007). Multikolinearitas dapat diatasi dengan pemberian pembobotan (cross section weight) atau GLS, sehingga parameter dugaan pada taraf uji tertentu (t-statistik maupun F-hitung) menjadi signifikan.

\section{Uji Autokorelasi}

Autokorelasi adalah korelasi yang terjadi antar observasi dalam satu variabel atau korelasi antar error masa yang lalu dengan error masa sekarang. Gujarati (2007) penaksiran model regresi linear memiliki asumsi bahwa tidak terdapat korelasi serial atau autokorelasi. Autokorelasi atau korelasi serial kemungkinan terjadi pada data time series. Model regresi yang baik tidak memperkenankan terjadinya autokorelasi. Akibat dari terjadinya autokorelasi adalah pengujian dalam uji $\mathrm{F}$ menjadi tidak valid dan jika diterapkan akan memberikan kesimpulan yang menyesatkan pada tingkat signifikansi dan koefisien regresi yang ditaksir. Pengujian untuk masalah autokorelasi dilakukan dengan melihat Durbin-Watson stat yang nilainya telah tersedia dalam program Eviews 6.0 dibandingkan dengan DW-Tabel. Sebuah model dikatakan terbebas dari autokorelasi jika nilai Durbin-Watson stat terletak di area nonautokorelasi. Penentuan area tersebut dibantu dengan nilai tabel $D L$ dan $D U$. Jumlah observasi $(\mathrm{N})$ dan jumlah variabel independen $(\mathrm{K})$. Hipotesis pengujian yang digunakan adalah sebagai berikut :

$\mathrm{H}_{0}=$ Tidak terdapat autokorelasi

$\mathrm{H}_{1}=$ terdapat autokorelasi

Tabel 1 Kriteria uji autokorelasi

\begin{tabular}{cc}
\hline Nilai DW & Hasil \\
\hline $0<\mathrm{DW}<\mathrm{dl}$ & Tolak H0, ada autokorelasi negatif \\
$\mathrm{d} l \leq \mathrm{DW} \leq \mathrm{du}$ & Tidak tentu, coba uji lain \\
$\mathrm{du} \leq \mathrm{DW}<4$-du & Terima H0, tidak ada autokorelasi \\
$4-\mathrm{du} \leq \mathrm{DW} \leq 4-\mathrm{dl}$ & Tidak tentu, coba uji lain \\
$4-\mathrm{dl}<\mathrm{DW}<4$ & Tolak H0, ada autokorelasi negatif \\
\hline
\end{tabular}

Sumber : Juanda, 2009

\section{Uji Heteroskedastisitas}

Uji heteroskedastisitas bertujuan untuk menguji apakah dalam sebuah model regresi terjadi ketidaksamaan varian dari residual untuk peubah bebas yang diketahui. Jika varian dari residual untuk peubah yang diketahui tetap, disebut dengan homokedastisitas. Jika varian berbeda disebut heterokedastisitas. Asumsi pada model regresi adalah varian setiap variabel independen mempunyai nilai yang konstan atau memiliki varian yang sama. Masalah heterokedastisitas umumnya terjadi pada data cross sectional. Konsekuensi dari adanya heterokedastisitas adalah kemungkinan untuk mengambil kesimpulan yang salah dari Uji F 
karena pengujian tingkat signifikansi yang kurang kuat (Gujarati, 2007). Untuk mendeteksi adanya heteroskedastisitas dalam model dilakukan dengan membandingkan nilai Sum Square Resid pada Weight Statistic dengan Sum Squared Resid Unweight Statistic. Jika Sum Square Resid pada Weight Statistic lebih kecil dari Sum Squared Resid Unweight Statistic, maka terjadi heteroskedastisitas. Untuk mengatasi masalah heteroskedastisitas, dilakukan dengan mengestimasi GLS menggunakan white-heteroscedasticity.

\subsection{Model Penelitian}

Model regresi yang digunakan dalam penelitian ini diadaptasi dari model yang digunakan oleh Erdinc dan Abazi (2014) dalam penelitian yang berjudul "The Determinants of NPLs in Emerging Europe 2000-2011". Adapun perbedaan penelitian ini dengan penelitian Erdinc dan Abazi (2014) adalah penggunaan variabel Net Income Margin (NIM), penambahan variabel bank size berdasarkan penelitian Firmansyah (2014) serta pengunaan variabel SBIS Rate berdasarkan penelitian Rahmawulan (2008). Selain itu terdapat penambahan variabel BI Rate dan Exchange Rate. metode yang digunakan adalah data panel statis dengan spesifikasi model sebagai berikut

$$
\begin{aligned}
& N P F_{i t}=a+b_{1} \text { FDR }_{i t}+b_{2} \text { CAR }_{i t}+b_{3} \text { NIM }_{i t}+b_{4} L N B A N K S I Z E_{i t}+b_{5} \text { LNOVERHEAD }_{i t}+b_{6} P P A P_{i t} \\
& +b_{7} K A P_{i t}+b_{8} S B I S R A T E_{i t}+b_{9} B_{I R A T E}+b_{10} L N E X R A T E_{i t}+\epsilon_{i t}
\end{aligned}
$$

Keterangan :

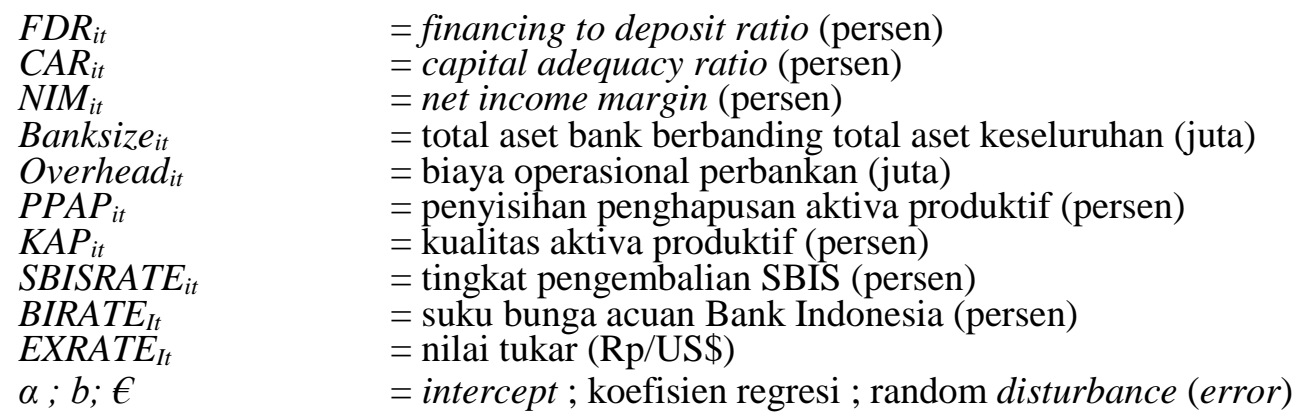

\section{Hasil dan Pembahasan}

\subsection{Hasil Estimasi Model}

Analisis data panel dilakukan untuk mengetahui faktor-faktor apa saja yang mempengaruhi Non Performing Financing pada Bank Umum Syariah. Regresi data panel dilakukan dengan tiga pendekatan, yaitu Pooled Least Square (PLS), Fixed Effect Model (FEM), Random Effect Model (REM). Dalam penelitian ini pendekatan yang digunakan adalah dengan Fixed Effect Model (FEM).

Tabel 3 Uji Chow dan Hausman terhadap NPF Bank Umum Syariah periode 2010-2014

\begin{tabular}{lll}
\hline \multicolumn{1}{c}{ Uji model terbaik } & \multicolumn{1}{c}{ Probabilitas } & \multicolumn{1}{c}{ Hasil hipotesis } \\
\hline Uji chow & 0.0001 & Tolak $\mathrm{H}_{0}$, maka FEM \\
Uji hausman & 0.0068 & Tolak $\mathrm{H}_{0}$, maka FEM \\
\hline
\end{tabular}

Sumber : output regresi data panel Eviews 6

Keterangan : $(*)(* *)(* * *)$ signifikan pada taraf nyata $1 \%, 5 \%, 10 \%$

Hasil uji chow model NPF menunjukkan nilai probabilitas sebesar 0.0001 nilai tersebut lebih kecil dari taraf nyata $5 \%$ sehingga model yang lebih baik adalah metode FEM. Setelah melakukan uji Jurnal Al-Muzara'ah Vol.4, No.1, 2016 
chow maka dilanjutkan dengan uji hausman untuk memilih model FEM atau REM yang akan digunakan. Hasil Uji Hausman menunjukkan nilai probabilitas sebesar 0.0068 lebih kecil dari taraf nyata 5\% sehingga model yang lebih baik adalah FEM. Dapat disimpulkan bahwa model terbaik yang dapat digunakan dalam mengestimasi tingkat non performing financing Bank Umum Syariah adalah metode FEM.

\subsection{Evaluasi Model Berdasarkan Kriteria Ekonometrika}

\subsubsection{Uji Normalitas}

Uji normalitas dilakukan untuk memeriksa apakah data residual penelitian menyebar normal atau tidak dengan menggunakan uji Skewness/Kurtosis .Hasil estimasi dapat dilihat pada Lampiran, menunjukkan nilai probabilitas Jarque Bera untuk NPF sebesar 0.323403 artinya error term sudah terdistribusi secara normal dalam model karena nilai Jarque Bera lebih besar dari taraf nyata $5 \%$.

\subsubsection{Uji Multikolinearitas}

Multikolinearitas disebabkan oleh nilai $\mathrm{R}^{2}$ tinggi namun variabel independennya hanya sedikit yang signifikan. Model dikatakan terbebas dari masalah multikolinearitas dengan melihat nilai Prob (F-Statistik) yang signifikan pada taraf nyata 5 persen. Pada model non performing financing bank umum syariah nilai $\mathrm{R}^{2} 0.872608$ yaitu dan terdapat 8 variabel independen yang signifikan dan 2 variabel yang tidak signifikan.

\subsubsection{Uji heteroskedastisitas}

Heteroskedastisitas dapat dilihat dengan membandingkan Sum Square Resid pada Weight Statistic dengan Sum Squared Resid Unweight Statistic. Jika Sum Square Resid pada Weight Statistic lebih kecil dari Sum Squared Resid Unweight Statistic, maka terjadi heteroskedastisitas. Hal ini dapat dilihat dari hasil estimasi model yang menunjukkan nilai Sum Square Resid Weight Statistic dari NPF sebesar 31.61995 lebih kecil dari Sum Squared Resid Unweight Statistic 36.33995 namun dalam mengestimasi model tersebut sudah dilakukan pembobotan dengan cross section weight maka asumsi adanya pelanggaran dapat diabaikan dengan demikian, model NPF pada Bank Umum Syariah terbebas dari masalah heteroskedastisitas.

\subsubsection{Uji autokorelasi}

Hasil regresi dengan metode FEM untuk model NPF pada bank umum syariah (Lampiran) menunjukkan nilai Durbin Watson statistic (DW-Stat) sebesar 2.189200. Dari tabel Durbin Watson dengan taraf nyata 5\%, $\mathrm{n}=55$ dan $\mathrm{k}=10$ maka didapatkan nilai batas bawah (DL) sebesar 1.170 dan nilai batas atas (DU) sebesar 2.010. Model yang terbebas dari masalah autokorelasi harus memiliki nilai statistik Durbin Watson diantara DU<DW <4-DU. Berdasarkan perhitungan tersebut, model NPF pada Bank Umum Syariah terbebas dari pelanggaran asumsi autokorelasi.

\subsection{Evaluasi Model Berdasarkan Kriteria Statistik}

\subsubsection{Koefisien Determinasi (R Squared)}

Hasil estimasi model NPF menunjukkan nilai R squared sebesar 0.872608. Nilai tersebut menunjukkan bahwa $87.2608 \%$ keragaman dari variabel dependen dapat dijelaskan oleh variabelvariabel independen, sedangkan sisanya dijelaskan oleh variabel lain diluar model.

\subsubsection{Uji F}

Hasil estimasi menunjukkan bahwa nilai F-statistic pada model NPF memiliki nilai 0.000000 
artinya model tersebut memiliki nilai F-Statistik yang lebih kecil dari taraf nyata 5\% sehingga dapat disimpulkan bahwa setidaknya ada satu variabel independen yang berpengaruh signifikan terhadap NPF Bank Umum Syariah.

\subsubsection{Uji T}

Hasil estimasi model NPF menunjukkan variabel independen yang memiliki nilai probabilitas lebih kecil dari nilai taraf nyata 5\% adalah CAR, NIM, SBIS dan BI rate. Variabel independen yang memiliki nilai probabilitas lebih kecil dari nilai taraf nyata $10 \%$ adalah FDR, Bank size, Biaya overhead dan KAP. Hal ini menunjukkan bahwa variabel-variabel independen tersebut secara parsial berpengaruh signifikan NPF Bank Umum Syariah.

\subsection{Evaluasi Model Berdasarkan Kriteria Ekonomi}

Evaluasi model estimasi berdasarkan kriteria ekonomi dilakukan dengan membandingkan kesesuaian tanda dan nilai estimator dengan teori ekonomi dan kesesuaian dengan logika. Hasil uji menunjukkan bahwa Fixed Effect Model (FEM) merupakan model terbaik pada penelitian ini

Tabel 4 Hasil estimasi pengaruh faktor internal dan ekternal terhadap NPF Bank Umum Syariah Periode 2010-2014

\begin{tabular}{lcl}
\hline Variabel & Koefisien & Prob \\
\hline FDR & 0.006216 & $0.0677^{* * *}$ \\
CAR & -0.028063 & $0.0120^{* *}$ \\
NIM & 0.189433 & $0.0139^{* *}$ \\
Banksize & -0.734519 & $0.0625 * * *$ \\
Overhead & -0.130097 & $0.0699^{* * *}$ \\
PPAP & 0.013327 & 0.2451 \\
KAP & 1.083312 & $0.0507^{* * *}$ \\
SBISRATE & -1.104378 & $0.0218^{* *}$ \\
BIRATE & 1.963394 & $0.0381^{* *}$ \\
LNEXRATE & 0.757268 & 0.8277 \\
C & -14.73628 & 0.6119 \\
\hline
\end{tabular}

Sumber : Output regresi data panel Eviews 6

Keterangan : $(* *)$ Signifikan pada taraf nyata 5 persen, $(* * *)$ Signifikan pada taraf nyata 10 persen

\subsubsection{Pengaruh Financing to Deposit Ratio (FDR) terhadap rasio NPF}

Hasil estimasi terhadap Non Performing Financing menggunakan analisis panel data dapat ditunjukan bahwa FDR memengaruhi NPF secara nyata dan signifikan dengan koefisien variabel sebesar 0.006216. Peningkatan FDR sebesar 1\% akan meningkatkan volume NPF sebesar 0.006 $\%$ dengan asumsi variabel lainya cateris paribus. Hasil penelitian ini sesuai dengan hipotesis awal yang menyatakan bahwa terdapat hubungan positif FDR terhadap pembiayaan bermasalah. Hasil ini didukung oleh penelitian Erdinc dan Abazi (2014) ketika LDR meningkat maka akan meningkatkan NPL pada bank yang melakukan penyaluran dana tersebut. Hubungan positif antara FDR dan NPF terjadi karena semakin tinggi jumlah dana yang disalurkan bank akan menimbulkan risiko pembiayaan yang sebanding. Nilai FDR yang tinggi dan masih dibawah batas maksimum yaitu sebesar $92 \%$ dimana sesuai ketentuan BI dianggap sehat. Ini menunjukkan bahwa jumlah dana di sektor perbankan tersebut digunakan secara maksimal dalam menyalurkan pembiayaan. 


\subsubsection{Pengaruh Bank size terhadap rasio NPF}

Berdasarkan hasil estimasi yang terdapat dalam Tabel 1 dapat ditunjukan bahwa bank size memiliki pengaruh yang nyata terhadap volume NPF pada Bank Umum Syariah. Nilai koefisien sebesar - 0.734519 menyatakan ketika bank size mengalami peningkatan sebesar $1 \%$ maka volume NPF mengalami penurunan sebesar 7.34519\% dengan asumsi variabel lainya cateris paribus. Hasil penelitian ini sesuai dengan hipotesis awal yang menyatakan bahwa terdapat hubungan negatif antara bank size dengan pembiayaan bermasalah. Menurut Misra dan Dhal (2010) pada saat perbankan memiliki jumlah aset yang lebih besar maka perbankan tersebut akan lebih selektif dalam memberikan pinjaman serta melakukan monitoring, yang menyebabkan tingkat risiko gagal bayar rendah. Pernyataan ini ditegaskan oleh penelitian Kurnia (2013) yang menyatakan bahwa besarnya aset yang dimiliki bank jika dikelola dan digunakan secara maksimal untuk kegiatan operasional bank, maka bank berpotensi mengeluarkan biaya pengelolaan aset yang lebih efisien. Hasil studi Ranjan dan Dahl (2003) juga menunjukkan bahwa semakin besar ukuran bank maka semakin kecil tingkat Non Performing Loan.

\subsubsection{Pengaruh Capital Adequacy Ratio (CAR) terhadap rasio NPF}

Hasil estimasi dalam Tabel 1 menjelaskan CAR memiliki pengaruh negatif signifikan terhadap volume NPF pada Bank Umum Syariah dengan koefisien - 0.028063. Ketika CAR mengalami peningkatan sebesar $1 \%$ maka volume NPF mengalami penurunan $0.03 \%$ dengan asumsi variabel lainnya cateris paribus. Hasil penelitian ini sesuai dengan hipotesis awal yang menyatakan bahwa terdapat hubungan negatif antara CAR dengan pembiayaan bermasalah. Hasil tersebut didukung oleh hasil penelitian Erdinc dan Abazi (2014), dengan hasil penelitian CAR berpengaruh negatif dan signifikan terhadap pemberian kredit. Hal ini menunjukkan bahwa semakin tinggi CAR maka semakin besar jumlah modal yang digunakan untuk menampung risiko kerugian gagal bayar. Dengan demikian CAR merupakan faktor penting dalam mitigasi risiko yang dilakukan perbankan terkait kemungkinan gagal bayar debitur dalam membayar pinjamannya.

\subsubsection{Pengaruh Kualitas Aktiva Produktif (KAP) terhadap rasio NPF}

Berdasarkan hasil estimasi yang terdapat dalam Tabel 1 menunjukkan bahwa KAP memiliki pengaruh signifikan positif terhadap volume NPF pada Bank Umum Syariah dengan koefisien 1.083312. Peningkatan $1 \%$ dari KAP akan mengakibatkan peningkatan volume NPF sebesar $1.08 \%$ dengan asumsi variabel lainya cateris paribus. KAP merupakan masalah krusial bagi perbankan, hal ini disebabkan KAP menunjukkan besaran pengembalian aktiva yang disalurkan. Hasil penelitian tidak sesuai dengan hipotesis awal yang menyatakan bahwa terdapat hubungan negatif antara komposisi KAP dengan pembiayaan bermasalah. KAP sangat sensitif terhadap NPF. Fahmi (2014) menyatakan bahwa penggolongan KAP terjadi atas dasar justifikasi apakah pembiayaan yang disalurkan berkualitas baik atau buruk. Selain itu, penetapan kualitas kredit/pembiayaan hanya berdasarkan pada prospek usaha, kemampuan debitur dalam mengembalikan pembiayaan serta kondisi keuangan debitur. Hasil studi Soebagio (2014) menyatakan hal sama bahwa KAP memilihi hubungan positif terhadap NPL.

\subsubsection{Pengaruh Net Income Margin (NIM) terhadap rasio NPF}

Hasil estimasi yang terdapat dalam Tabel 1 dapat ditunjukan bahwa NIM memiliki pengaruh yang nyata terhadap volume NPF pada Bank Umum Syariah. Koefisien NIM sebesar 0.189433 menyatakan ketika NIM mengalami peningkatan sebesar $1 \%$ maka volume NPF mengalami peningkatan $0.19 \%$ dengan asumsi variabel lainya cateris paribus. Hasil penelitian ini tidak sesuai dengan hipotesis awal yang menyatakan bahwa ada hubungan negatif dan signifikan antara NIM dan NPF. Berdasarkan ketentuan pada peraturan BI No.5/2003, salah satu proxy dari risiko pasar adalah suku bunga. NIM mengukur kemampuan manajemen bank dalam mengelola aktiva produktif untuk menghasilkan pendapatan bersih. Hal ini menunjukkan bahwa NIM menggambarkan kemampuan bank dalam memperoleh pendapatan. operasional dari dana yang 
ditempatkan dalam bentuk pembiayaan. NIM yang besar bagus untuk pertumbuhan perbankan namun hal ini akan membebani para debitur yang harus membayar beban pinjaman yang tinggi, sehingga hal ini akan berdampak pada kemungkinan terjadi risiko gagal bayar. Selain itu nilai NIM menunjukkan biaya intermediasi yang dilakukan oleh bank sehingga NIM menjadi salah satu indikator dari efisiensi sistem perbankan.

\subsubsection{Pengaruh Biaya Overhead terhadap rasio NPF}

Biaya overhead merupakan biaya operasional perbankan yang berhubungan langsung dengan periode terjadinya. Biaya overhead meliputi biaya gaji pegawai, tunjangan-tunjangan, biaya penyusutan aktiva tetap, biaya listrik, biaya air serta biaya alat tulis kantor. Berdasarkan hasil estimasi yang terdapat dalam Tabel 4 dapat ditunjukan bahwa biaya overhead memiliki pengaruh yang nyata terhadap volume NPF pada bank umum syariah, dengan koefisien -0.130097 . Hal ini menyatakan bahwa saat biaya overhead mengalami peningkatan sebesar $1 \%$ maka volume NPF mengalami penurunan sebesar $0.13 \%$ dengan asumsi variabel lainya cateris paribus. Hasil penelitian ini tidak sesuai dengan hipotesis awal yang menyatakan bahwa terdapat hubungan positif antara biaya overhead dengan pembiayaan bermasalah. Hubungan negatif tersebut disebabkan karena biaya overhead merupakan biaya operasional perbankan dalam kegiatan sehari-hari. Hal ini menunjukkan bahwa semakin tinggi biaya overhead maka kegiatan operasional bank menjadi kurang efisien karena meningkatnya biaya overhead akan memengaruhi return on asset pada bank tersebut. Nilai return on asset yang menurun mengakibatkan dana yang disalurkan dalam bentuk pembiayaan akan turun sehingga kemungkinan risiko gagal bayar juga turun. Selain itu biaya overhead termasuk kedalam monitoring cost yang artinya semakin tinggi biaya overhead maka tingkat kemungkinana gagal bayar bisa ditekan.

\subsubsection{Pengaruh BI rate terhadap rasio NPF}

BI rate oleh Bank Indonesia didefinisikan sebagai suku bunga kebijakan yang mencerminkan sikap atau stance kebijakan moneter yang ditetapkan Bank Indonesia. Pengaruhnya BI rate terhadap NPF pada Bank Umum Syariah tidak terlepas dari akad yang digunakan dalam pembiayaan. Komposisi pembiayaan pada bank syariah didominasi oleh pembiayaan akad murabahah yang mana pada prinsip jual beli murabahah pendapatan yang diperoleh bank bersifat tetap sebab margin yang ditetapkan oleh pihak bank terhadap debitur telah ditentukan di awal. Berbeda dengan pembiayaan dengan akad bagi hasil mudharabah dan musyarakah yang mana bagi hasil bergantung pada untung/rugi pihak debitur (Antonio, 2001), maka saat debitur mengalami kerugian bank syariah tidak akan mendapatkan bagi hasil dan justru dapat pula menanggung risiko kerugian bersama debitur.

Hasil estimasi yang terdapat dalam Tabel 4 dapat ditunjukan bahwa BI Rate memiliki pengaruh yang nyata terhadap volume NPF pada bank umum syariah, dengan koefisien 1.963394. Saat BI Rate mengalami peningkatan sebesar $1 \%$ maka volume NPF mengalami peningkatan $1.96 \%$ dengan asumsi variabel lainya cateris paribus. Hasil penelitian sesuai dengan hipotesis awal yang menyatakan bahwa terdapat hubungan positif antara BI Rate dengan pembiayaan bermasalah. Saat BI Rate naik, maka nisbah bagi hasil pada Bank Umum Syariah akan mampu bersaing dengan tingkat bunga pinjaman yang ditetapkan oleh bank. Hal ini menunjukkan produk pembiayaan yang ditawarkan oleh Bank Umum Syariah akan semakin kompetitif. Artinya saat BI Rate naik akan diikuti dengan naiknya suku bunga kredit bank konvensional. Sedangkan margin atau nisbah bagi hasil bank syariah yang ditentukan oleh kapasitas usaha atau laba atau rugi debitur tidak bisa naik begitu saja, maka margin tersebut akan lebih bersaing terhadap suku bunga kredit bank. Debitur akan cenderung mencari bunga yang lebih rendah saat melakukan pinjaman, maka saat suku bunga kredit bank konvensional naik akibat kenaikan BI Rate maka debitur akan memilih opsi lain yakni melakukan pinjaman atau pembiayaan pada bank syariah yang biaya dananya dianggap lebih rendah dibandingkan bunga bank konvensional yang sedang 
meningkat.

\subsubsection{Pengaruh SBIS rate terhadap rasio NPF}

Hasil estimasi yang terdapat dalam Tabel 1 dapat ditunjukan bahwa SBIS memiliki pengaruh yang nyata terhadap volume NPF pada Bank Umum Syariah, dengan koefisien -1.104338. Saat terjadi peningkatan SBIS sebesar 1\% maka volume NPF mengalami penurunan $1.1 \%$ dengan asumsi variabel lainya cateris paribus. Hasil penelitian ini sesuai dengan hipotesis awal yang menyatakan bahwa terdapat hubungan negatif antara SBIS dengan pembiayaan bermasalah. Pengaruh negatif tersebut dikarenakan SBIS memiliki karakteristik yang berbeda dengan SBI, seperti yang tertera pada Peraturan Bank Indonesia Nomor 10/11/PBI/2008. Perbedaannya terletak pada mekanisme return pada keduanya, SBI berdasarkan tingkat suku bunga tanpa mempedulikan kemungkinan untung maupun rugi atas investasi, sedangkan SBIS menggunakan akad ju'alah atau sesuai dengan kemanfaatan yang diperoleh (Fatwa Dewan Syariah Nasional Majelis Ulama Indonesia Nomor 64/DSN-MUI/XII/2007). Selain itu saat peningkatan SBIS rate membawa insentif bagi bank untuk menanamkan dananya dalam bentuk investasi dibanding melakukan pembiayaan. Hal ini dikarenakan penanaman dana dalam bentuk SBIS memberikan tingkat risiko yang rendah dari pada risiko pembiyaaan, sehingga pembiayaan akan turun dan risiko gagal bayar juga turun.

\section{Kesimpulan dan Saran}

\subsection{Kesimpulan}

Berdasarkan penelitian yang telah dilakukan maka diperoleh kesimpulan bahwa Variabel internal perbankan dan kondisi makroekonomi yang berpengaruh pada NPF adalah FDR, Bank size, Net Income Margin, biaya Overhead, CAR dan KAP sedangkan variabel eksternal yang mempengaruhi NPF adalah BI Rate dan SBIS Rate. Variabel FDR, NIM, KAP dan BI rate berpengaruh positif signifikan terhadap NPF sedangkan variabel CAR, bank size, biaya overhead, serta SBIS rate berpengaruh negarif signifikan terhadap NPF.

\subsection{Saran}

Berdasarkan penelitian yang telah dilakukan, terdapat beberapan saran yang dapat peneliti berikan, diantaranya:

1. Perbankan Bank Umum Syariah perlu melakukan pengawasan terhadap tingkat Capital Adequacy Ratio (CAR) karena berdasarkan hasil uji estimasi nilai CAR berpengaruh dalam menurunkan NPF, akan tetapi tingkat CAR tetap harus dijaga agar tetap berada pada nilai batas yang ditetapkan oleh Bank Indonesia. Selain itu, Bank Umum Syariah perlu melakukan pengawasan terhadap tingkat biaya overhead sehingga dalam kegiatan operasional biaya overhead yang digunakan dapat lebih efisien.

2. Bank Umum Syariah harus lebih peka terhadap kondisi makroekonomi terutama tingkat BI Rate dan tingkat imbal hasil SBIS sehingga dapat menentukan kebijakan pembiayaan secara tepat agar dapat mengendalikan tingkat NPF pada taraf yang wajar.

3. Penelitian selanjutnya dapat menggunakan variabel internal lain seperti tingkat suku bunga pinjaman bank serta variabel eksternal lain seperti tingkat pengangguran. Selain itu dapat juga dengan memperluas cakupan objek penelitian serta menganalisis dari sisi internal debitur. 


\section{Daftar Pustaka}

Adebolla SS, Yusoff WSBW, Dahalan J. 2011. An ARDL Approach to the Determinants of NonPerforming Loans In Islamic Banking System In Malaysia. [Jurnal].Kuwait Chapter of Arabian Journal of Business and Management Review. Vol 11 (2): 20-30.

Berger A, Deyoung R. (1997). Problem Loans and Cost Efficiency in Commercial Banks. [Jurnal]. Journal of Banking and Finance. Vol 21: 849-870.

Dash MK , Kabra G. (2010). The determiants of nonperforming asset in India Commercial Banks: An economic Study. [Jurnal]. Middle Eastern Finance and Economics.Vol 7:93-106.

Dendawijaya L. 2005. Manajemen Perbankan. Bogor(ID): Ghalia Indonesia.

Diyanti. 2012. Analisis Pengaruh Faktor Internal dan Ekternal Terhadap Terjadinya NonPerforming Loan. [Skripsi].Universitas Diponegoro.

Erdinc D, Abazi E. 2014. The Determinants of NPLs in Emerging Europe, 2000-2011. [Jurnal]. Journal of Economis and Political Economy. Vol 1 (2) : 112-125.

Fahmi I. 2014. Manajemen Perkreditan. Alfabeta : Bandung. Faisal

Faiz, Ihda A. 2010. "Ketahanan Kredit Perbankan Syariah Terhadap Krisis Keuangan Global". [Jurnal]. Jurnal ekonomi Islam La Riba. Vol 4(2).

Firdaus M. 2012. Aplikasi Ekonometrika untuk Data Panel dan Time Series.

Bogor (ID): IPB Press.

Firmansyah I. 2014. Determinants of Non Performing Loan: The Case of Islamic Bank in Indonesia. [Jurnal]. Jakarta(ID): Buletin Ekonomi Moneter dan Perbankan. Vol 17 (2).

Gujarati D. 2007. Dasar- dasar Ekonometrika. Jilid 2. Jakarta (ID) : Salemba Empat

Ismail. 2010. Manajemen Perbankan dari Teori Menuju Aplikas. Jakarta : Kencana

Juanda B. 2012. Ekonometrika Deret Waktu: Teori dan Aplikasi. Bogor(ID): IPB Press.

Kurnia DJ. 2013. Analisis Faktor-Faktor Yang Mempengaruhi Non-Performing Loan (Studi Pada Bank Umum Konvensional yang Go Public di Indonesia Periode 2008-2012). [Skripsi].Universitas Diponegoro.

Louzis DP, Vouldis AT, Metaxas VL. 2012. Macroeconomic and Bank-specific Determinants of Non-performing Loans in Greece: A comparative study of mortgage, business and consumer loan portfolios. [Jurnal]. Athena(GR): Journal of Banking \& Finance. Vol 36 : 1012-1027.

Mileris R. 2012. Macroeconomic Determinants of Loan Portfolio Credit Risk in Banks. [Jurnal]. Panevezys(LT): Inzinerine Ekonomika-Engineering Economics. Vol 23(5) : 496-504.

Misra BM, Dhal S. 2010. "Pro-Cyclical Management of Non-Performing Loans by the Indian Public Sector Banks". BIS Asian Research Papers.

Antonio MS. 2001.Bank Syariah dari Teori ke Praktek. Gema Insani : Jakarta.

Nkusu M. 2011. Nonperforming Loans and Macrofinancial Vulnerabilities in Advanced Economies. Working Paper IMF. WP/11/161

[OJK] Otoritas Jasa Keuangan. 2009. Statistik Perbankan Syariah Desember 20102014.[internet]. [diunduh 2015 Februari 20]. Tersedia pada : http://www.ojk.go.id.

Rahmawulan, Y, 2008. Perbandingan Faktor Penyebab Timbulnya NPL dan NPF Pada Perbankan Konvensional dan Syariah di Indonesia. [Tesis]. Universitas Indonesia.

Ranjan R, Dhal SC. (2003). Non-Performing Loans and Terms of Credit of Public Sector Banks in India: An Empirical Assessment. [Jurnal]. Occasional Papers. Vol 24(3): 81-121

Scarica B .2014. Determinants of Non-Performing Loans in Central An Eastern Eourope Countries. [Jurnal]. Financial theory and practice. Vol 38 (1) : 37-59.

Socol A, Danuletiu AE. 2013. Analysis of the Romanian Banks Performance Through ROA, ROE and Non-Performing Loans Models. [Jurnal]. Annales Universitatis Apulensis Series Oeconomica. Vol 15(2) : 594-604

Soebagio H. 2005. Analisis Faktor-faktor yang Mempengaruhi terjadinya Non Performing Loan (NPL) pada Bank Umum Komersil. [Tesis].Universitas Diponegoro Semarang.

Wu WC, Chang CO, Selvili Z. 2003. Banking System, Real Estate Markets and Non Performing Loans. International Real Estate Review. Vol 6 (1): 43-62 


\section{LAMPIRAN}

Lampiran 1 Hasil Estimasi Panel Data dengan Menggunakan Fixed Effect Model dengan Pembobotan (Cross-section Weight) dan White Periode terhadap Model NPF Bank Umum Syariah 2010-2014

Dependent Variable: NPF

Method: Panel EGLS (Cross-section weights)

Date: 07/01/15 Time: 07:39

Sample: 20102014

Periods included: 5

Cross-sections included: 11

Total panel (balanced) observations: 55

Linear estimation after one-step weighting matrix

White period standard errors \& covariance (d.f. corrected)

WARNING: estimated coefficient covariance matrix is of reduced rank

\begin{tabular}{crrrr}
\hline \hline Variable & Coefficient & Std. Error & t-Statistic & Prob. \\
& & & & \\
\hline \hline FDR & 0.006216 & 0.003293 & 1.887362 & 0.0677 \\
CAR & -0.028063 & 0.010576 & -2.653371 & 0.0120 \\
NIM & 0.189433 & 0.073033 & 2.593818 & 0.0139 \\
LNBANKSIZE & -0.734519 & 0.381326 & -1.926223 & 0.0625 \\
LNOVERHEAD & -0.310097 & 0.165678 & -1.871685 & 0.0699 \\
PPAP & 0.013327 & 0.011267 & 1.182838 & 0.2451 \\
RPPAP & 1.083312 & 0.534805 & 2.025621 & 0.0507 \\
SBIS & -1.104378 & 0.459443 & -2.403732 & 0.0218 \\
BIRATE & 1.963394 & 0.910022 & 2.157523 & 0.0381 \\
LNEXRATE & 0.757268 & 3.354186 & 0.225768 & 0.8227 \\
C & -14.73628 & 28.77719 & -0.512082 & 0.6119 \\
& & & & \\
\hline \hline
\end{tabular}

Effects Specification

Cross-section fixed (dummy variables)

Weighted Statistics

R-squared

Adjusted R-squared

Mean dependent var

3). 18072818

S.E. of regression

S.D. dependent var

2.).394683

F-statistic

Sum squared resid

B1965145654

Prob(F-statistic)

2.1 12963

Durbin-Watson stat

0.000000

UnweightedStatistics

R-squared

0.780774 Mean dependent var

2.736727

Sum squared resid 36.33994 Durbin-Watson stat

2.361351 
Lampiran 2 Hasil Uji -F (Chow Test) terhadap Model NPF Bank Umum Syariah 2010-2014

Redundant Fixed Effects Tests

Equation: Untitled

Test cross-section fixed effects

\begin{tabular}{lccc}
\hline \hline Effects Test & Statistic & d.f. & Prob. \\
\hline \hline Cross-section F & 5.485894 & $(10,34)$ & 0.0001 \\
\hline \hline
\end{tabular}

Sumber : Output regesi data panel Eviews 6

Lampiran 3 Hasil Uji Hausman (Hausman Test) terhadap Model NPF Bank Umum Syariah 2010-2014

Correlated Random Effects - Hausman Test

Equation: Untitled

Test cross-section random effects

\begin{tabular}{lll}
\hline \hline & Chi-Sq. & \\
Test Summary & Statistic Chi-Sq. d.f. Prob.
\end{tabular}

\begin{tabular}{llll}
\hline \hline Cross-section random & 24.305894 & 10 & 0.0068
\end{tabular}

** WARNING: estimated cross-section random effects variance is zero.

Sumber : Output regesi data panel Eviews 6 
Lampiran 4 Hasil Uji multikolinearitas antarvariabel pada model NPF Bank Umum Syariah 2010-2014

\begin{tabular}{|c|c|c|c|c|c|c|c|c|c|c|c|}
\hline & NPF & FDR & CAR & NIM & LNBANKSIZE & LNOVERHEAD & PPAP & RPPAP & SBIS & BIRATE & LNEXRATE \\
\hline NPF & 1.000000 & -0.030562 & -0.395726 & -0.228515 & 0.387720 & 0.402935 & 0.006999 & 0.665662 & 0.220894 & 0.305450 & 0.330012 \\
\hline FDR & -0.030562 & 1.000000 & 0.177021 & -0.070458 & 0.005091 & -0.132920 & -0.233570 & -0.044401 & -0.064390 & -0.037749 & 0.004204 \\
\hline CAR & -0.395726 & 0.177021 & 1.000000 & -0.026660 & -0.724279 & -0.565307 & 0.168637 & -0.450964 & -0.051477 & -0.135062 & -0.271150 \\
\hline NIM & -0.228515 & -0.070458 & -0.026660 & 1.000000 & 0.058993 & 0.225469 & -0.054250 & 0.074202 & -0.150599 & -0.168983 & -0.174107 \\
\hline LNBANKSIZE & 0.387720 & 0.005091 & -0.724279 & 0.058993 & 1.000000 & 0.860125 & -0.208851 & 0.586438 & 0.095279 & 0.168231 & 0.270666 \\
\hline LNOVERHEAD & 0.402935 & -0.132920 & -0.565307 & 0.225469 & 0.860125 & 1.000000 & -0.250253 & 0.603258 & 0.123881 & 0.159530 & 0.208384 \\
\hline PPAP & 0.006999 & -0.233570 & 0.168637 & -0.054250 & -0.208851 & -0.250253 & 1.000000 & 0.018664 & 0.081228 & 0.017901 & -0.097939 \\
\hline RPPAP & 0.665662 & -0.044401 & -0.450964 & 0.074202 & 0.586438 & 0.603258 & 0.018664 & 1.000000 & 0.127933 & 0.158193 & 0.201782 \\
\hline SBIS & 0.220894 & -0.064390 & -0.051477 & -0.150599 & 0.095279 & 0.123881 & 0.081228 & 0.127933 & 1.000000 & 0.951053 & 0.764681 \\
\hline BIRATE & 0.305450 & -0.037749 & -0.135062 & -0.168983 & 0.168231 & 0.159530 & 0.017901 & 0.158193 & 0.951053 & 1.000000 & 0.898827 \\
\hline LNEXRATE & 0.330012 & 0.004204 & -0.271150 & -0.174107 & 0.270666 & 0.208384 & -0.097939 & 0.201782 & 0.764681 & 0.898827 & 1.000000 \\
\hline
\end{tabular}

